anales de psicología, 2017, vol. 33, $\mathrm{n}^{\circ} 1$ (january), 188-195 http://dx.doi.org/10.6018/analesps.33.1.256911
C Copyright 2017: Servicio de Publicaciones de la Universidad de Murcia. Murcia (Spain) ISSN print edition: 0212-9728. ISSN web edition (http://revistas.um.es/analesps): 1695-2294

\title{
Adaptation into European Spanish of the Automated Working Memory Test Battery (AWMA)
}

\author{
Miguel Á. Pérez ${ }^{1, *}$, Flávia H. Santos ${ }^{2}$, , Lidia Gómez-Cobos ${ }^{1}$, Lorenzo Hernández-Pallarés ${ }^{3}$, Victoria Cuello ${ }^{3}$, \\ Concha Miralles ${ }^{3}$, Javier Marín ${ }^{1}$ y Gema Cañizares ${ }^{3}$ \\ 1 University of Murcia (Spain). \\ 2 University of Minho, Laboratory of Human Cognition (Portugal). \\ 3 Consejería Educación y Universidades, Región de Murcia (Spain).
}

\begin{abstract}
Título: Adaptación al Español Europeo de la Evaluación Automatizada de la Memoria Operativa (Automated Working Memory Test Battery AWMA).

Resumen: En el presente estudio se presenta la adaptación al idioma Español Europeo de la Evaluación Automatizada de la Memoria Operativa, habiéndose tenido en cuenta la necesidad de calibración para cuestiones de acento y lingüística que no son compatibles con la versión disponible. Con este propósito, el material verbal fue seleccionado cuidadosa y apropiadamente, teniendo en cuenta las especificidades del Español Europeo y con el fin de controlar los posibles efectos de los factores psicolingüísticos, tales como la longitud de las palabras o la frecuencia léxica, y aspectos técnicos, como la velocidad de presentación de los estímulos y la calidad de sonido también fueron controlados. Una muestra exploratoria de 81 niños de 7 a 9 años de edad se evaluó para confirmar que la adaptación es adecuada para su empleo posterior. Además las puntuaciones obtenidas se contrastaron con las de niños argentinos. Los datos mostraron una validez adecuada y una puntuación fiable, lo que permite considerar a esta versión como un instrumento útil para fines de investigación, y su empleo en futuros estudios debería incentivar la recopilación de datos normativos para españoles.

Palabras clave: memoria operativa; evaluación; español europeo; infancia; psicolingüística.
\end{abstract}

\section{Introduction}

Working memory is a broad framework of interacting processes that involve the temporary storage and manipulation of information ongoing complex cognitive activities. In the original frame proposed by Baddeley and Hitch (1974) there were three components: the central executive, a limited capacity controller characterized as a collection of attentional control, planning and monitoring, and retrieval resources (Baddeley, 1996), which was supported by two modality specific temporary storage systems, the phonological loop and the visuo-spatial sketchpad. Two decades later, a fourth component, the episodic buffer was included (Baddeley, 2000). The episodic buffer was understood as a temporary multidimensional store that binds information from the temporary storage subsystems, long-term memory, and the central executive. It was assumed as a consciousness function (Baars, 2002).

Alloway, Gathercole, Kirkwood, \& Elliott (2009) carried out an epidemiological study in 3,189 native Englishspeaking children using two working memory tasks in the screening phase. They found out a sample of 361 children

* Correspondence address [Dirección para correspondencia]

Dr. Flávia Heloísa Santos, University of Minho. School of Psychology (CIPsi). Gabinete 1098. Campus de Gualtar, 4710-057, Braga (Portugal). E-mail: flaviahs@psi.uminho.pt

Dr. Miguel Á. Pérez, Facultad de Psicología, Campus de Espinardo

(Edif. 31), Universidad de Murcia, 30100, Murcia (Spain).

E-mail: maperez@um.es
Abstract: The current study presents the adaptation of Automated Working Memory Assessment into European Spanish, considering the need of calibration for accent and linguistic issues not supported by the version available. For this purpose, verbal material was carefully and properly selected, considering specificities of the European Spanish, in order to control possible effects of psycholinguistic factors, such as word length or lexical frequency, and technical aspects such as stimuli presentation speed and sound quality were also tuned. An exploratory sample of 81 children from 7- to 9-year-old was assessed to confirm that the adaptation is suitable for further use, besides, their scores were contrasted with the Argentinean children. The data showed proper validity and reliability scores, which characterize this version as a useful instrument for research purposes, and its usage in further studies should be encourage to gather normative data for Spaniards.

Key word: working memory; assessment; European Spanish; childhood; psycholinguistic

aged 5-6 and 9-10 years that obtained scores at or below the 10 th percentile in contrast with their age group. These children with low working memory capacity were assessed in other domains such as cognitive skills (IQ, vocabulary, reading, and math), classroom behavior, and self-esteem. Children with low working memory capacity presented high ratings of cognitive problems / inattentive symptoms and were judged to have short attention spans, high levels of distractibility, problems in monitoring the quality of their work, and difficulties in generating new solutions to problems. Therefore, working memory is a sensible marker in the context of academic achievement and learning disabilities; besides, working memory predicts longer term academic success (Alloway, Alloway, \& Wootan, 2014).

In fact, working memory deficits are associated with disorders in reading (e.g., López-Escribano, Elosúa de Juan, Gómez-Veiga, \& García-Madruga, 2013; Wang \& Gathercole, 2014), mathematics (e.g., Geary, Hoard, Byrd-Craven, \& DeSoto, 2004; Santos et al., 2012; Pina, Fuentes, Castillo, \& Diamantopoulou, 2014), language (e.g., Archibald \& Gathercole, 2006; Bandini, Santos, \& Souza, 2013; Holmes et al., 2015), and attention (e.g. Martinussen \& Tannock, 2006; Gathercole, Alloway, Kirkwood, \& Elliott, 2008; Holmes et al., 2014). Therefore, its assessment is relevant in clinical context.

The AWMA is a computer based standardized battery that assesses both temporary storage and attentional control (Alloway, 2007). However, develop and standardize equiva- 
lent neuropsychological instruments across different languages respecting cross-cultural issues is challenge (Santos et al., 2012). Especially in the context of working memory because socioeconomic status seems do not affect working memory performance (Engel, Santos, \& Gathercole, 2008; Alloway et al., 2014), however environmental stimulation does (Tine, 2014).

The battery was originally generated in English and it has been translated and used into 15 languages, such as Argentinean-Spanish (Injoque-Ricle, Calero, Alloway, \& Burin, 2011). The Argentinean-Spanish AWMA was validated in children aged 6, 8 and 11 years. The tasks were well understood by all children, and their performance showed a steady increase in difficulty as a function of item size, or to-beremembered items, mainly in the three verbal tests (InjoqueRicle et al., 2011). The authors also found a high internal consistency (Cronbach's $\alpha$ ), and in other study, using factorial confirmatory analysis observed age-related changes in working memory structure (Injoque-Ricle, Barreyro, \& Burin, 2012).

It would be desirable to adapt the instrument in a way that it could be suitable for all Spanish-speakers in the world. However, developing a "neutral" Spanish version of any assessment without translators of different Hispanic subgroups is unattainable given regional differences (Smith et al., 2011). Besides, electrophysiological evidence indicates that processing foreign-accent interferes with comprehension for native European Spanish speakers (Romero-Rivas, Martin \& Costa, 2015).

The aim of the current article is to provide an initial calibration of Spanish, concerning Argentinean and European Spanish. The study presents an adaptation that accounts for specificities of the European Spanish, such as the accent, idiomatic expressions, and lexical aspects, such as frequency of words, length, and syllabic structure. Moreover, some formal aspects related to stimuli presentation, such as speed presentation of word and numbers, and sound quality were controlled. Finally, data from 7-, 8- and 9-year-old children were obtained in order to analyze the psychometric features of the present adaptation before advance for normative studies in Spain.

\section{Method}

\section{Participants}

Eighty-one monolingual Spanish speaking children participated in the study. They belonged to three age groups: 7-,
8-, and 9-year-old. Children attended three middle-class public elementary-level schools in the province of Murcia, Spain. According information provided from educational counselors, children diagnosed with psychiatric or neurological conditions, language or hearing impairment were not included in the study. Some descriptive statistics are shown in Table 1 .

Table 1. Number of participants by gender and age.

\begin{tabular}{lccccc}
\hline \multirow{2}{*}{ Age group } & \multicolumn{3}{c}{$N$} & \multicolumn{2}{c}{ Age } \\
\cline { 2 - 6 } & Total & Male & Female & Mean & S.D. \\
\hline 7-years-old & 27 & 8 & 19 & 7.8 & .21 \\
8-years-old & 27 & 16 & 11 & 8.5 & .19 \\
9-years-old & 27 & 16 & 11 & 9.2 & .27 \\
All & 81 & 40 & 41 & 8.5 & .22 \\
\hline
\end{tabular}

\section{Adaptation Procedure}

\section{Instructions}

Instructions of the current version were adapted taking into account both the instructions of the Argentinean and English versions of the AWMA. The instructions explain each task in a clear and concise language.

\section{Sentences}

Sentences used in the task 'Listening recall' were those used in the Argentinean version, although some words and expressions had to be adapted to those usually used in Spain (e.g, 'bananas' was substituted by 'plátanos', 'colectivos' by 'autobuses', 'autos' by 'coches', 'chanchos' by 'cerdos', etc.).

\section{Words}

Words used in the task 'Word recall' were selected from mono- and disyllabic-words of Spanish, accounting psycholinguistic variables such as familiarity and lexical frequency in Spain (Pérez \& Navalón, 2005; Pérez, Alameda, \& Cuetos, 2003; Davis \& Perea, 2005). Selected words were grouped into several sets containing from 2 to 7 words each, with a similar syllable structure distribution. The sets with the same number of words were controlled for number of phonemes and syllables, and block of sets were matched in average lexical frequency (no significant differences, $p<.05$, were found between t-test comparisons; see Table 2). The fact that two or more words semantically associated or phonologically similar (e.g, in rhyme) belong to the same set was also avoided. 
Table 2. Words and pseudowords' characteristics.

\begin{tabular}{|c|c|c|c|c|c|c|c|}
\hline $\begin{array}{l}\text { Groups } \\
\text { of sets } \\
\end{array}$ & Some used words ${ }^{a}$ & Syllables per word (mean) & $\begin{array}{c}\text { Phonemes per } \\
\text { word (mean) }\end{array}$ & Log. LF & Some used pseudowords a & $N$ (mean) & $P($ mean $) \mathrm{b}$ \\
\hline 1 word & dedo & 1.7 & 3.7 & 1.5 & goco & $6.2^{b} / 7.5^{c}$ & 2.1 \\
\hline 2 words & gris \& uva & 1.5 & 3.5 & 1.3 & grus \& uda & $6.6^{b} / 10^{\mathrm{c}}$ & 2.3 \\
\hline 3 words & zona, hacha, etc. & 1.7 & 3.7 & 1.4 & icha, rona, etc. & $4.5^{b} / 5.4^{c}$ & 1.6 \\
\hline 4 words & cruz, ola, etc. & 1.8 & 3.8 & 1.2 & ope, bruf, etc. & $4.5^{b} / 5.4^{c}$ & 1.6 \\
\hline 5 words & roca, nudo, etc. & 1.8 & 3.8 & 1.1 & tarre, cudo, etc. & $5.7 \mathrm{~b} / 5.2^{\mathrm{c}}$ & 2.0 \\
\hline 6 words & mesa, amo, etc. & 1.7 & 3.5 & 1.6 & ode, mosa, etc. & $4.9^{\mathrm{b}} / 6.4^{\mathrm{c}}$ & 1.8 \\
\hline 7 words & don, foca, etc. & 1.7 & 3.6 & 1.4 & nan, foña & $6.2^{b} / 7.8^{c}$ & 2.1 \\
\hline
\end{tabular}

Log. LF, mean logarithm of lexical frequencies $[\log (x+1)]$ from LEXESP (Sebastián, Cuetos, Martí, \& Carreiras, 2000). Log. LF, mean logarithm of lexical frequencies $[\log (x+1)]$. $N$, orthographical neighborhood. $P$, phonological neighborhood,

a, Two items of each block are only presented because of copyright limitations.

b, from David \& Perea (2005), based on the corpus collected by Sebastián et al. (2000).

c, from Pérez, Alameda, \& Cuetos (2003), based on the dictionary of the Royal Spanish Academy.

\section{Pseudowords}

Pseudowords were generated from the variation of one or two phonemes in the words used in the task 'Word recall'. Thus, formal characteristics of pseudowords were similar to those of words, and also between sets with the same or different number of pseudowords. Groups of sets of different length also showed equivalent mean scores in orthographical and phonological neighborhood (no significant differences, $p$ $<.05$, were found between t-test comparisons; see Table 2). None of the pseudowords generated is considered as a word in the dictionary of the Royal Spanish Academy. (This material can be requested to Pearson, see www.psychcorp.co.uk).

\section{Recording and editing of materials}

For the purpose of maintaining sound characteristics similar to other versions of AWMA, instructions and test stimuli were recorded by a young woman, who maintained a neutral accent (i.e. a standard pronunciation of Spanish sounds; entirely recognized in all territories of Spain) and a natural intonation in the case of stimuli. Each item was recorded several times in order to select subsequently the clearest in pronunciation. Audio files were edited to improve sound quality and to control for some stimuli's features. To improve the sound quality, background noise was removed and sound intensity was matched among all recordings. To control for some stimuli's features: 1) the selected recordings of numbers were always used in each and every one of the list belonging to the tasks 'Digit recall', and 'Backward digit recall'; 2) the same inter-stimuli interval (i.e. a silence of 350 $\mathrm{ms}$ ) was introduced in the tasks 'Digit recall', 'Backward digit recall', 'Word recall', and 'Nonword recall', so the presentation rate of stimuli was constant for each list in those tasks. The interval was established from an estimation of the interstimuli gaps average existing in the original test in English.

\section{Instruments}

The original AWMA is copyrighted (C) 2007 by Pearson Assessment. The translation and adaptation into European Spanish were carried out with permission of the editor and with knowledge of the author. The AWMA produces four composites with three tasks each, all of the increasing the number of items in order to access working memory capacity across different sources of stimuli, which are: i) verbal shortterm memory: 'Digit recall', 'Word recall', and 'Nonword recall'. ii) visuospatial short-term memory: 'dot matrix', 'mazes memory task', 'block recall'. iii) verbal working memory: 'Listening recall', 'Backward digit recall', and 'Counting recall', and iv) visuospatial working memory: 'Odd-one-out', 'Mr. X', 'Spatial recall'. Tasks were detailed and described in Alloway, (2007). The psychometric properties of AWMA were reported by Alloway, Gathercole, and Pickering (2006), whereas convergent and divergent validity were shown by several studies (e.g., Alloway, Gathercole, Kirkwood, \& Elliott, 2008; Gathercole et al., 2008).

Other domains were assessed: executive functions (ENFEN, Evaluación Neuropsicológica de las Funciones Ejecutivas en Niños; Portellano, Martínez \& Zumárraga, 2009), reading (TECLE, Test Colectivo de Eficacia Lectora; Marín \& Carrillo, 1999), and processing speed (Coding subtest from WISC-IV, Wechsler, 2005) were also applied. ENFEN was composed for several subtest: phonetic fluency, semantic fluency, grey path (linking numbers in decreasing order), colors path (linking numbers in increasing order but alternating the color of the number each time), rings (similar to $\mathrm{Ha}-$ noi tower task), and Stroop-kind interference. TECLE is an against the clock reading test consisting in selecting the word (from 4 choices) that properly completes a sentence. Finally, Coding subtest from WISC-IV consists in writing as fast as possible the correct symbol above each paired number.

\section{Procedures}

Educational counselors, teachers and parents were informed about the study, and the last signed an informed consent in order to allow their children to participate. A written report was provided for the regarding educational counselor. Each child was tested by a trained experimenter in a quiet room inside the school he or she attended. Each children completed all AWMA tasks in 1 or 2 sessions, depending school eventualities, lasting approximately $45 \mathrm{~min}$ overall. 
Table 3. Descriptive statistics for AWMA tasks.

\begin{tabular}{|c|c|c|c|c|c|c|c|c|}
\hline & $\mathrm{N}$ & Minimun & Maximun & Mean & Median & Standard deviation & Skewness & Kurtosis \\
\hline Digit recall & 81 & 15 & 35 & 24.2 & 24 & 4.0 & .246 & .325 \\
\hline Word recall & 81 & 18 & 27 & 21.8 & 22 & 2.2 & -.043 & -.911 \\
\hline Nonword recall & 81 & 9 & 22 & 16.0 & 16 & 2.6 & .006 & .016 \\
\hline Listening recall & 81 & 5 & 26 & 12.5 & 13 & 3.3 & .424 & 2.783 \\
\hline Counting recall & 81 & 7 & 33 & 19.1 & 18 & 5.1 & .320 & -.025 \\
\hline Backwards digit recall & 81 & 6 & 20 & 11.5 & 12 & 3.2 & .368 & -.022 \\
\hline Dot matrix & 81 & 13 & 34 & 24.1 & 24 & 4.5 & -.113 & -.094 \\
\hline Mazes memory & 81 & 3 & 39 & 21.9 & 22 & 5.0 & -.172 & 2.758 \\
\hline Block recall & 81 & 12 & 35 & 23.1 & 23 & 4.6 & -.146 & .020 \\
\hline Odd-one-out task & 81 & 7 & 30 & 17.9 & 18 & 4.4 & .277 & 1.349 \\
\hline Mister x & 81 & 1 & 23 & 11.3 & 12 & 5.1 & .067 & -.619 \\
\hline Spatial recall & 81 & 5 & 31 & 17.1 & 17 & 4.7 & .251 & .217 \\
\hline
\end{tabular}

\section{Results}

Table 3 shows the descriptive statistics for the score obtained in each AWMA task. The relative low values of skewness suggest a normal distribution for AWMA subtest, which was confirmed with a Kolmogorov-Smirnov test for all subtest, except for Word recall $(Z=1.420, p<.05)$. Therefore, for the next analyses we performed the parametric as well as non-parametric analyses, when necessary.

\section{Age comparisons}

Figure 1 shows mean scores and confidence intervals at 95\% obtained in each AWMA task and age group. From confidence intervals we can see better scores for 8-year-old than for 7-year-old children in Counting recall, Dot matrix, Mazes memory, Block recall, and Mr. X. Better scores for 9year-old than for 8-year-old children in Backward digit recall, Odd-one-out task and Mr. X; And finally better scores for 9year-old than for 7-year-old in all the subtest except in Digit recall, Word recall, Nonword recall and Spatial recall.

Moreover, one factor ANOVA and a non-parametric test were carried out to assess if there were significant differences in memory scores along the 3 age groups. Both analyses had similar results that significant differences between age groups were found in Listening recall, Counting recall, Dot matrix, Mazes memory, Block recall, Odd-one-out task, and Mr. X (see Table 4).
Figure 1. Mean scores for each age group in Spain and Argentina.

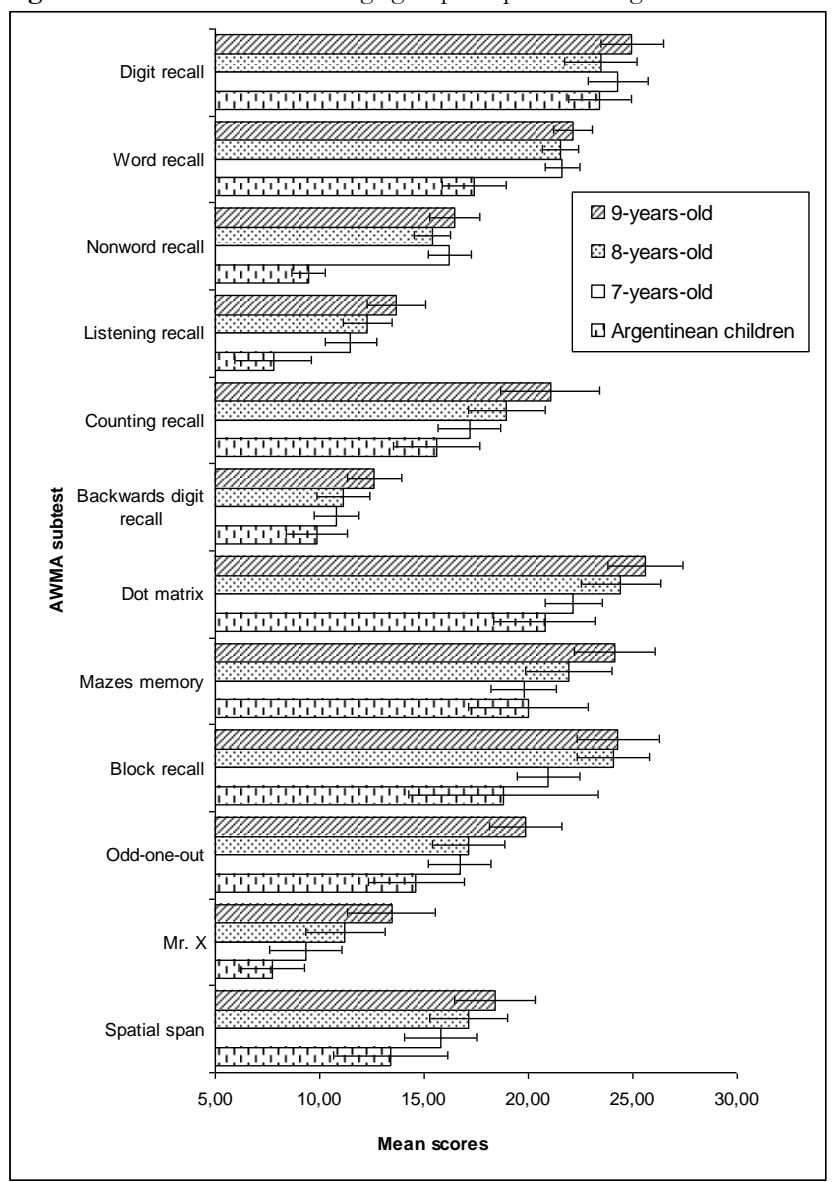


Table 4. Mean comparison of AWMA tasks across age groups.

\begin{tabular}{|c|c|c|c|c|c|c|c|c|}
\hline & \multicolumn{3}{|c|}{ Age group } & \multicolumn{3}{|r|}{ ANOVA } & \multicolumn{2}{|c|}{ Non parametrical test } \\
\hline & 7-years-old & 8-years-old & 9 -years-old & $\mathrm{F}(2,80)$ value & $p$ & Significant paired comparisons ${ }^{\text {a }}$ & $U(2)$ value $^{\mathrm{b}}$ & $p$ \\
\hline Digit recall & 24.3 & 23.4 & 25.0 & .997 & .373 & & 1.626 & .444 \\
\hline Word recall & 21.6 & 21.5 & 22.1 & .628 & .536 & & 1.181 & .554 \\
\hline Nonword recall & 16.2 & 15.4 & 16.5 & 1.239 & .295 & & 2.531 & .282 \\
\hline Listening recall & 11.5 & 12.3 & 13.7 & 3.217 & .045 & 7 vs. 9 & 5.763 & .056 \\
\hline Counting recall & 17.2 & 19.0 & 21.0 & 4.231 & .018 & 7 vs. 9 & 7.973 & .019 \\
\hline Backwards digit recall & 10.8 & 11.1 & 12.6 & 2.651 & .077 & & 3.921 & .141 \\
\hline Dot matrix & 22.1 & 24.4 & 25.6 & 4.524 & .014 & 7 vs. 9 & 10.600 & .005 \\
\hline Mazes memory & 19.8 & 21.9 & 24.1 & 5.698 & .005 & 7 vs. 9 & 12.671 & .002 \\
\hline Block recall & 21.0 & 24.1 & 24.3 & 4.761 & .011 & 7 vs. 8 and 7 vs. 9 & 10.671 & .005 \\
\hline Odd-one-out & 16.7 & 17.1 & 19.9 & 4.615 & .013 & 7 vs. 9 & 6.382 & .041 \\
\hline Mr. X & 9.3 & 11.2 & 13.4 & 4.833 & .011 & 7 vs. 9 & 8.317 & .016 \\
\hline Spatial recall & 15.8 & 17.1 & 18.4 & 2.102 & .129 & & 3.897 & .142 \\
\hline
\end{tabular}

a, Significant $(p<.05)$ post-hoc paired comparisons, $t$-test with Bonferroni correction. b, Kruskal-Wallis for 3 independent samples.

\section{Reliability}

Internal consistency (Cronbach's $\alpha$ ) was calculated for blocks of verbal and visuo-spatial tasks and for all tasks together. Reliability coefficients from the parallel-forms method were also obtained. Appropriate values were obtained in all blocks and methods (see Table 5).

Table 5. Reliability coefficients.

\begin{tabular}{lr}
\hline Analyzed tasks and method & Value \\
\hline All tasks & $.882^{\text {a }}$ \\
Verbal tasks (digit recall, word recall, nonword recall, listening & .781 a \\
recall, counting recall, and backwards digit recall) & \\
Visuo-spatial tasks (dot matrix, mazes memory, block recall, & .863 a \\
ood-one-out, Mister X, and spatial recall) $^{\text {Correlations between forms }{ }^{\text {b }}}$ & .786 \\
Spearman-Brown coefficient $^{\mathrm{b}}$ & .880 \\
Guttman method $^{\mathrm{b}}$ & .869 \\
\hline
\end{tabular}

a, internal consistency (Cronbach's $\alpha$ ). b, form 1 (Digit recall, Dot matrix, Listening recall, Odd-one-out, Word recall, and Mazes memory) and form 2 (Counting recall, Mister X, Nonword recall, Block recall, Backwards digit recall, Spatial recall).

\section{Validity}

In order to check the internal convergent validity paired Pearson's correlations between the tasks were carried out (see Table 6). Significant medium and high size positive correlations were found between all subtests (between .237 and .701), except in seven correlations between pairs of subtests belonging verbal and visual tasks: Digit recall and Dot matrix, Digit recall and Mazes memory, Digit recall and Mr. X, Word recall and Mazes memory, Nonword recall and Dot matrix, Nonword recall and Block recall, and Backwards digit recall and Listening recall.

Table 6. Correlation matrix between AWMA tasks.

\begin{tabular}{|c|c|c|c|c|c|c|c|c|c|c|c|c|}
\hline & DR & WR & NWR & LR & CR & BDR & $\overline{\mathrm{DM}}$ & MM & $\overline{B R}$ & $\mathrm{OOO}$ & MX & SR \\
\hline Digit recall (DR) & 1.000 & & & & & & & & & & & \\
\hline Word recall (WR) & $.542 * *$ & 1.000 & & & & & & & & & & \\
\hline Nonword recall (NWR) & $.479 * *$ & $.419 * *$ & 1.000 & & & & & & & & & \\
\hline Listening recall (LR) & $.399 * *$ & $.474 * *$ & $.269 *$ & 1.000 & & & & & & & & \\
\hline Counting recall (CR) & $.411 * *$ & $.404 * *$ & $.276^{*}$ & $.542 * *$ & 1.000 & & & & & & & \\
\hline Backwards digit recall (BDR) & $.415^{* *}$ & $.271 *$ & $.286 * *$ & .198 & $.558 * *$ & 1.000 & & & & & & \\
\hline Dot matrix $(\mathrm{DM})$ & .097 & $.238^{*}$ & .057 & $.286 * *$ & $.502 * *$ & $.331 * *$ & 1.000 & & & & & \\
\hline Mazes memory (MM) & .043 & .186 & $.263^{*}$ & $.338 * *$ & $.386 * *$ & $.280 *$ & $.530 * *$ & 1.000 & & & & \\
\hline Block recall (BR) & $.237^{*}$ & $.375^{* *}$ & .134 & $.300 * *$ & $.562 * *$ & $.506 * *$ & $.526 * *$ & $.389 * *$ & 1.000 & & & \\
\hline Odd-one-out (OOO) & $.252 *$ & $.274 *$ & $.341 * *$ & $.254^{*}$ & $.438 * *$ & $.478^{* *}$ & $.447 * *$ & $.559 * *$ & $.416^{* *}$ & 1.000 & & \\
\hline Mister $\mathrm{x}(\mathrm{MX})$ & .133 & $.411 * *$ & $.326 * *$ & $.432 * *$ & $.553 * *$ & $.448 * *$ & $.559 * *$ & $.466 * *$ & $.527 * *$ & $.444 * *$ & 1.000 & \\
\hline Spatial recall (SR) & $.329 * *$ & $.333 * *$ & $.374 * *$ & $.322 * *$ & $.571 * *$ & $.544 * *$ & $.589 * *$ & $.468 * *$ & $.489 * *$ & $.597 * *$ & $.701 * *$ & 1.000 \\
\hline
\end{tabular}

Table 7 shows correlations between AWMA scores and ENFEN subtests, TECLE, and Coding (subtest of WISC IV). With respect to external convergent validity, positive and significant correlations were found between some of AWMA subtests and the entire ENFEN subtests (phonemic fluency, semantic fluency, grey path, colors path, rings, and Stroop interference), and the reading skill test. On the other hand, with respect to discriminant validity, no significant correlations were found between any of the AWMA subtests and Coding task. 
Table 7. Correlations between AWMA tasks and other cognitive tests.

\begin{tabular}{|c|c|c|c|c|c|c|c|c|}
\hline & & & $\mathrm{EN}-\mathrm{S}$ & est & & & & \\
\hline & Phonetic Flu & ntic Fl & srey Pat & olors $\mathrm{Pa}$ & Rings. & $b$ interfe & TECLE & g (WISC-IV) \\
\hline Digit recall (DR) & .177 & .145 & .026 & $.258^{*}$ & .080 & .017 & $.329 * *$ & -.066 \\
\hline Word recall (WR) & $.318^{* *}$ & .167 & .208 & .208 & .198 & .143 & $.261 *$ & .032 \\
\hline Nonword recall (NWR) & .102 & .159 & -.064 & .121 & -.074 & .006 & .099 & -.095 \\
\hline Listening recall (LR) & $.358 * *$ & .122 & .178 & .211 & $.302 * *$ & .146 & $.279 *$ & -.004 \\
\hline Counting recall (CR) & $.481^{* *}$ & $.264^{*}$ & $.313^{* *}$ & .198 & $.282^{*}$ & $.336 * *$ & $.461 * *$ & .146 \\
\hline Backwards digit recall (BDR) & $.414^{* *}$ & $.239 *$ & $.253 *$ & $.224 *$ & .160 & .161 & $.346 * *$ & .146 \\
\hline Dot matrix (DM) & $.398 * *$ & .175 & $.421 * *$ & .149 & $.371 * *$ & $.185^{* *}$ & $.295^{* *}$ & .080 \\
\hline Mazes memory (MM) & $.234^{* *}$ & .144 & $.309 * *$ & $.226^{*}$ & $.343^{* *}$ & $.209 * *$ & .098 & .151 \\
\hline Block recall (BR) & $.336 * *$ & .204 & $.336^{* *}$ & $.223^{*}$ & $.289 * *$ & $.465^{* *}$ & $.477 * *$ & .208 \\
\hline Odd-one-out (OOO) & $.353^{* *}$ & $.216^{*}$ & $.306^{* *}$ & $.313^{* *}$ & $.354^{* *}$ & $.317^{* *}$ & .126 & .065 \\
\hline Mister $\mathrm{x}(\mathrm{MX})$ & $.436^{* *}$ & .082 & $.255^{*}$ & .110 & $.249 *$ & .128 & $.336^{* *}$ & .143 \\
\hline Spatial recall (SR) & $.335^{* *}$ & $.259 *$ & $.247^{*}$ & $.249 *$ & $.280^{*}$ & .215 & $.301 * *$ & .089 \\
\hline
\end{tabular}

\section{Comparison with the Argentinean sample}

We also include in Figure 1 the mean scores (and confidence intervals at 95\%) obtained by Argentinean children from 6-, 8- and to 11-years-old (70 participants per agegroup, $N=210$, mean age $=8.8$ years, s.d. $=0.26$; see Injoque-Ricle et al., 2011) as an external reference to compare the performance of children tested here. Better scores were obtained by Spanish versus Argentinean samples in all subtest comparisons, $t(80) \geq 2.400, p<0.05$, except for Digit recall, $t(80)=1.485, p>0.05$.

\section{Discussion}

The current work presents the translation and adaptation of AWMA into European Spanish. Verbal material was carefully and properly selected in order to control possible effects of psycholinguistics factors, such as word length or lexical frequency. Some other more technical aspects related to stimuli presentation speed and sound quality were also tuned. Controls on verbal material taken into account suggest how working memory tests can be improved, in order to avoid unwanted influence from some psycholinguistics variables.

We have found a slightly better performance for children from Spain compared to the Argentinean sample (i.e. samples with a similar mean age) for all AWMA subtests, except for Digit recall (Injoque-Ricle et al., 2011, 2012). Firstly, this means that scores showed are within those expected for the age of children, and therefore, we can assume that instructions were properly understood by children. Secondly, verbal subtest that we have adapted into European Spanish does not cause a different performance level with respect to those expected for the unmodified visual subtest. Although we have not compared statistically our data with those from Alloway et al. (2006), average scores from our sample are also similar to those obtained in 7-8- and 9-11-year-old English samples (see Table 2 of Alloway et al., 2006).

Assessed children in general showed scores in AWMA that progressively increased with age. We have found slightly differences between 7- vs. 9-year-old children in seven subtests, and we also found some differences in some subtest between 7-vs. 8-, and 8- vs. 9-year-old children. The increasing of working memory capacity associated with age has been shown in numerous previous studies (e.g., Alloway et al, 2006; Gathercole, 1998; Gathercole, Pickering, Ambridge, \& Wearing, 2004; Santos \& Bueno, 2003; Santos, Mello, Bueno, \& Dellatolas, 2005).

Regarding reliability, a high internal consistency and adequate parallel-forms correlations were observed, which are similar to the internal consistence found by Injoque-Ricle et al. $(2011,2012)$ in the Argentinean version and the test-retest scores obtained by Alloway et al. (2006) in the English version. Regarding internal convergent validity, correlation matrix among subtests showed from moderate to high correlations, being almost all statistically significant. These results are consistent with those presented by Injoque-Ricle et al. (2011) and Alloway et al. (2006), where all correlations were moderate to high and significant. External convergent validity was based on moderate and significant correlations with several executive function tasks (phonetic fluency, semantic fluency, grey path, colors path, rings, and Stroop interference), in which working memory is involved (Portellano et al., 2009). Also, significant correlations were obtained with reading skill, which development has been associated with working memory capacity (e.g., Dixon, LeFevre, \& Twilley, 1988). Finally, non-significant correlations with processing speed (Coding task from WISC-IV) were found, which is consistent with previous findings (Williams, Weiss, and Rolfhus, 2003). In other study, the correlation between a working memory test and Coding is low: $r=.24$ (Harcourt Assessment, 2005).

The sample was small due to its exploratory purpose, which was to verify if the adaptation of AWMA into European Spanish has equivalent psychometric properties as the original. Results encourage the next step that is to obtain normative data in Spain, which is essential for clinical and education application. 


\section{Conclusions}

Overall, the adaptation of AWMA into European Spanish completes other previously done. It provides improvement on verbal material by controlling some psycholinguistics variables. Proper reliability and validity indexes were achieved. Therefore, this version seems suitable for research purposes.

\section{References}

Alloway, T. P. (2007). Automated working memory assessment. London: Psychological Corporation.

Alloway, T. P., Alloway, R., \& Wootan, S. (2014). Home sweet home: Does where you live matter to working memory and other cognitive skills? Journal of Experimental Child Psychology, 124, 124-131. doi: 10.1016/j.jecp.2013.11.01

Alloway, T. P., Gathercole, S. E, Kirkwood, H. J., \& Elliott, J. E. (2008). Evaluating the validity of the Automated Working Memory Assessment. Educational Psychology, 7, 725-734. doi: $10.1080 / 01443410802243828$

Alloway, T. P., Gathercole, S. E, Kirkwood, H. J., \& Elliott, J. E. (2009). The cognitive and behavioural characteristics of children with low working memory. Child Development, 80, 606-621. doi: 10.1111/j.14678624.2009.01282.x

Alloway, T. P., Gathercole, S.E., \& Pickering, S. J. (2006). Verbal and visuospatial short-term and working memory in children: Are they separable? Child Development, 77, 1698-1716. doi: 10.1111/j.14678624.2006.00968.x

Archibald, L. M. D., \& Gathercole, S. E. (2006). Short-term and working memory in children with Specific Language Impairments. International Journal of Language and Communication Disorders, 41, 675-693. doi: $10.1080 / 13682820500442602$

Baars, B. J. (2002). The conscious access hypothesis: Origins and recent evidence. Trends in Cognitive Sciences, 6, 47-52. doi: 10.1016/S13646613(00)01819-2

Baddeley, A. D. (1996). Exploring the central executive. Quarterly Journal of Experimental Psychology, 49 A, 5-28. doi: 10.1080/713755608

Baddeley, A. D. (2000). The episodic buffer: a new component of working memory? Trends in Cognitive Sciences, 11, 417-423. doi:10.1016/S13646613(00)01538-2

Baddeley, A. D., \& Hitch, G. J. (1974). Working memory. In G. H. Bower (Ed.), Psychology of learning and motivation, vol. 8 (pp. 47-89). New York: Academic Press. doi:10.1016/S0079-7421(08)60452-1

Bandini, H. H. M., Santos, F. H., \& Souza, D. G. (2013). Levels of phonological awareness, working memory, and lexical knowledge in elementary school children. Paidéia, 23, 329-337. doi: 10.1590/198243272356201307

Davis, C. J., \& Perea, M. (2005). BuscaPalabras: A program for deriving orthographic and phonological neighborhood statistics and other psycholinguistic indices in Spanish. Behavior Research Methods, 37, 665-671.doi: 10.3758/BF03192738

Dixon, P., LeFevre, J. A., \& Twilley, L. C. (1988). Word knowledge and working memory as predictors of reading skill. Journal of Educational Psychology, 80, 465-472. doi: 10.1037/0022-0663.80.4.465

Engel, P., Santos, F.H., \& Gathercole, S. E. (2008). Are working memory measures free of socio-economic influence? Journal of Speech, Language, and Hearing Research, 51, 580-1587. doi: 10.1044/1092-4388

Gathercole, S. E, Alloway, T. P., Kirkwood, H. J., \& Elliott, J. E. (2008). Attentional and executive function behaviors in children with poor working memory. Learning and Individual Differences, 18, 214-223. doi: 10.1016/j.lindif.2007.10.003

Gathercole, S. E. (1998). The development of memory. Journal of Child Psychology and Psychiatry, 39, 3 - 27.

Gathercole, S. E., Pickering, S. J., Ambridge, B., \& Wearing, H. (2004). The structure of working memory from 4 to 15 years of age. Developmental Psychology, 40, 177 - 190. doi: 10.1037/0012-1649.40.2.177
However, further research is needed to obtain normative data across lifespan in Spaniards, and mainly in children.

Acknowledgments.- This research was supported mainly by two grants from the Fundación Séneca, Murcia Regional Government Agency for Science and Technology (visiting research grant 2010 to Flávia Heloísa Dos Santos and research grant 19463/PI/14), and by a grant from the Spanish Minister of Science and Innovation (research grant PSI2008-03481/PSIC).

Geary, D. C, Hoard, M. K., Byrd-Craven, J. \& DeSoto, M. C. (2004). Strategy choices in simple and complex addition: Contributions of working memory and counting knowledge for children with mathematical disability. Journal of Experimental Child Psychology, 88, 121-151. doi:10.1016/j.jecp.2004.03.002

Harcourt Assessment, Inc. (2005). Correlations Between the CELF-4 and WISC-4 Integrated (Technical report). Retrieved from Pearson website: http://www.pearsonassessments.com/hai/images/resource/techrpts/ CELF4_WISC4_TechReport.pdf

Holmes, J., Butterfield, S., Cormack, F., Loenhoud, A., Ruggero, L., Kashikar L., \& Gathercole, S. (2015). Improving working memory in children with low language abilities. Frontiers in Psychology, 6: 519. doi: 10.3389/fpsyg.2015.00519.

Holmes, J., Hilton, K.A., Place, M., Alloway, T. P., Elliott, J. G., \& Gathercole, S. E. (2014). Children with low working memory and children with ADHD: same or different?. Frontiers Human Neurosciences, 8:976. doi: 10.3389/fnhum.2014.00976.

Injoque-Ricle, I., Barreyro, J. P., \& Burin, D. I. (2012). Working Memory Structure in Children: Comparing Different Models during Childhood. Escritos de Psicología, 5, 27-38. doi: 10.5231/psy.writ.2012.1904

Injoque-Ricle, I., Calero, A. D., Alloway, T. P., \& Burin, D. I. (2011). Assessing working memory in Spanish-speaking children: Automated Working Memory Assessment Battery Adaptation. Learning and Individual Differences, 21, 78-84. doi: 10.1016/j.lindif.2010.09.012

López-Escribano, C., Elosúa de Juan, M. R., Gómez-Veiga, I., GarcíaMadruga, J. A. (2013). A predictive study of reading comprehension in third-grade Spanish students. Psicothema, 25, 199-205. doi 10.7334/psicothema2012.175

Marín, J., \& Carrillo, M. S. (1999). Test Colectivo de Eficacia Lectora (TECLE). Departamento de Psicología Básica y Metodología. Universidad de Murcia.

Martinussen, R., \& Tannock, R. (2006). Working memory impairments in children with attention-deficit hyperactivity disorder with and without comorbid language learning disorders. Journal of Clinical and Experimental Neuropsychology, 28, 1073-1094. doi: 10.1080/13803390500205700

Pérez, M. A., \& Navalón, C. (2005). Objective-AoA norms for 175 names in Spanish: Relationships with other psycholinguistic variables, estimated AoA, and data from other languages. European Journal of Cognitive Psychology, 17, 179-206. doi: 10.1016/j.jecp.2004.03.002

Pérez, M. A., Alameda, J. R., \& Cuetos, F. (2003). Frecuencia, longitud y vecindad ortográfica de las palabras de 3 a 16 letras del Diccionario de la Lengua Española (RAE, 1992). Revista Electrónica de Metodología Aplicada, 8, 1-10. (http://www.unioviedo.es/reunido/index.php/Rema/index)

Pina, P., Fuentes, L. J., Castillo, A., \& Diamantopoulou, S. (2014). Disentangling the effects of working memory, language, parental education, and non-verbal intelligence on children's mathematical abilities. Frontier in Psychology, 5: 415. doi: 10.3389/fpsyg.2014.00415

Portellano Pérez, J. A, Martínez Arias, R., \& Zumárraga Astorqui, L. (2009). ENFEN, Evaluación neuropsicológica de las funciones ejecutivas en niños. Madrid: Tea Ediciones.

Romero-Rivas, C., Martin, C. D., \& Costa, A., (2015). Processing changes when listening to foreign-accented speech. Frontiers in Human Neurosciences, 9:167. doi: 10.3389/fnhum.2015.00167

Santos, F. H., \& Bueno, O. F. A. (2003). Validation of the Brazilian Children's Test of pseudoword repetition in Portuguese speakers aged 4 to 10 years. Brazilian Journal of Medical and Biological Research, 36, 33-47. 
Santos, F. H., Mello, C. B., Bueno, O. F. A., \& Dellatolas, G. (2005). Crosscultural differences for three visual memory tasks in Brazilian children. Perceptual Motor Skills, 101, 421- 433. doi:10.2466/pms.101.2.421-433

Santos, F. H., Silva, P. A., Dias, A. L. R. P., Ribeiro, F. S., Frigério, M. C., Dellatolas, G., \& von Aster, M. (2012). Number processing and calculation in Brazilian children aged 7-12 years. Spanish Journal of Psychology, 15, 513-25. doi: 10.5209/rev_SJOP.2012.v15.n2.38862

Sebastián, N., Cuetos, F., Martí, M.A., \& Carreiras, M.F. (2000). LEXESP: Léxico informatizado del español. Barcelona: Edicions de la Universitat de Barcelona.

Smith, T. L., Klein, M. H., Alonso, C., Salazar-Fraile, J., Felipe-Castaño, E., Moreno C. L., Acosta, S. R., Rios, L. I., \& Martí-Sanjuán, V. (2011). The Spanish version of the Wisconsin Personality Disorders InventoryIV (WISPI-IV): Tests of validity and reliability. Journal of Personality Disorders, 25, 813-833.
Tine, M. (2014). Working Memory differences between children living in rural and urban Poverty. Journal of Cognition and Development, 15, 599-613. doi: 10.1080/15248372.2013.797906

Wang, S., \& Gathercole, S. E. (2013). Working memory deficits in children with reading difficulties: Memory span and dual task coordination. Jour nal of Experimental Child Psychology, 115, 188-197. doi: 10.1016/j.jecp.2012.11.015

Wechsler, D. (2005). Test de Inteligencia para niños WISC-IV. Madrid: Pearsons.

Williams, P. E., Weiss, L. G., \& Rolfhus, E. L. (2003). WISC-IV Technical Report \#2. Psychometric Properties. Retrieved from Pearson website: http://www.pearsonassessments.com/hai/Images/pdf/wisciv/WISCI VTechReport2.pdf

(Article received: 19-042016; revised: 10-08-2016; accepted: 13-10-2016) 